\title{
Satisfaction And Contribution Of Stakeholders From The Performance Prism Model
}

\author{
Elizandra Severgnini ${ }^{\dagger}$ \\ Universidade Estadual de Maringá \\ Edwin Vladimir Cardoza Galdaméz ${ }^{\Omega}$ \\ Universidade Estadual de Maringá \\ Romildo de Oliveira Moraes $¥$ \\ Universidade Estadual de Maringá
}

\section{ABSTRACT}

In the process of performance evaluation it is essential to define the needs, capacities and contributions of stakeholders. The objective of this paper is to analyze the perception of managers of Micro, Small and Medium Enterprises (MSMEs) in relation to the Satisfaction and Contribution of Stakeholders to organizational performance. The research was conducted with 7 MSMEs. The results from the interviews showed that (i) there is a broader understanding of who are the most important stakeholders, opposing the view of the owners and customers and (ii) the contribution of stakeholders expected by the business is more subjective, considering the continuity of the relationship with the parties and a delivery of superior value. Finally, the results provided the basis for the proposition of new dimension called Expectations of Continuity and Partnership as an element to assess stakeholder contribution.

Keywords: Stakeholders, Performance Prism, Small and Medium Enterprises.

\section{INTRODUCTION}

Performance evaluation is relevant in the construction of a strategy of organizational excellence (CHOONG, 2013). It is a practice that emerges at a time when the organization needs to understand different economic scenarios, create different evaluation perspectives, gauge results and generate support for decision-making.

The process of organizational performance management, in addition to the financial perspective, has valued non-financial perspectives. Among the main models are the Balanced Scorecard(KAPLAN; NORTON, 1997) and the Performance Prism- PP (NEELY et al, 2001), which promote evaluation from perspectives related to learning, capabilities, processes, innovation, customers and stakeholders.

Nogning and Gardoni, (2015) and $\mathrm{Wu}$ (2009) highlight that in the literature there is an effort to establishcomparisons and complementarities among performance evaluation models (STRITESKA; PICKOVA, 2012), in reporting the evolution (CARPINETTI; GALDÁMEZ; GEROLAMO, 2008) and determine applicability in large organizations (SOUSA; CARPINETTI; GROESBECK; VAN-AKEN, 2005).

One of the main contributions of the PP is the Participation and Contribution of Stakeholders in the performance of the organization (NEELY et al, 2001). Defining the role of stakeholders is key to
Corresponding author:

† Universidade Estadual de Maringá

E-mail: elisevergnini@gmail.com

$\Omega$ Universidade Estadual de Maringá

E-mail: evcgaldamez@uem.br

${ }^{¥}$ Universidade Estadual de Maringá

E-mail: romoraes@usp.br

Received: 03/28/2016.

Revised: 05/12/2016.

Accepted: 08/11/2016.

Published Online: 08/01/2017 
planning, implementing and delivering feedback on proposed improvement actions from different organizational perspectives.

Stakeholder Theory is a useful lens to explain how stakeholders influence and are influenced by the organization and other stakeholders (FREEMAN, 1984; CLARKSON, 1995; DONALDSON; PRESTON, 1995; BRIDOUX; STOELHORST, 2014). Searcy (2012), from on a literature review, comments on the relevance of studying stakeholders and evaluating performance, but does not generate empirical evidence. Rodrigue, Magnan and Boulianne (2013) also investigated the relationship between stakeholder and environmental management, but did not consider a performance evaluation model.

We can observe that there is an opportunity to investigate how the Stakeholders Theory helps to understand or even broaden the perspective of stakeholders of the PP. This study becomes more evident when considering the application of Stakeholder Theory and PP in Micro, Small and Medium Enterprises (MSMES) with respect to the performance management process, since the literature disseminates results only on large organizations (SOUSA; ASPINWALL; GUIMARÃES, 2006; JAMIL; MOHAMED, 2011; GARENGO; BIAZZO; BITITCI, 2005; NOGNING; GARDONI, 2015; WU, 2009).

The objective of this study is to use an analysis of the perception of managers of MSMEs regarding the Satisfaction and Contribution of Stakeholders to the process of performance evaluation of the organization. Specifically, the Stakeholders Theory is considered as a basis for scientific observation and the PP Model as a reference for identifying needs, perspectives and contributions of stakeholders on organizational performance.

From the research it is possible to expand the analysis of Stakeholders Theory from three to four perspectives, proposed by Donaldson and Preston (1995) and used to assess and define the role of stakeholders in the process of performance evaluation. The contribution is made by identifying who the organization's stakeholders are and what the owners expect from them. The PP dimension analysis was constructed using a multiple case study of several MSMEs (STAKE, 2013), interviewing managers regarding stakeholder perspectives.

In the next item we present the Stakeholders Theory, the PP Model and the relationship between the Stakeholders Theory and the PP Model. Subsequently, the empirical research method is highlighted: multiple case study in MSMEs. Following, we list the final considerations and suggestions for future research.

\section{THEORETICAL FRAMEWORK}

\subsection{STAKeHOLders THEORY}

For the Stakeholder Theory, developed by Freeman (1984), the definition of stakeholders denominated as those interested parties or interest groups of an organization (HORNEAUX, 2010; HORNEAUX et al., 2014), it is "...all persons or institutions that have, in any way, claims, interests, property rights in a company or in its activities, in the present, past or future" (CLARKSON, 1995, p. 106).

In the traditional view, shareholders or stockholders are the owners of the organization, who has the duty to put their needs first, increasing their value (FREEMAN; REED, 1983). Thus, the goal is profit (FREEMAN; WICKS; PARMAR, 2004). However, in the stakeholder theory view there are other stakeholders (HORNEAUX, 2010) and considers that people or institutions are understood as employees, consumers, suppliers, financial institutions, communities, government, political parties and groups, business and trade associations and workers or labor unions (FREEMAN 1984; 1994).

The Theory of Stakeholders broadens the organization's vision to the external environment and allows the use of non-financial indicators and to verify the relationship of the external environment with the organizational behavior (FREEMAN, 1984). Therefore, 
BBR

15,2

several actors are taken into account for the decision-making and elaboration of strategies (HARRISON; FREEMAN, 1999). There is a perspective of placing Stakeholders as actors that influence strategies (FROOMAN, 1999) and the responses to natural disasters (MCKINIGHT; LINNENLUECKE, 2016).

One contribution of the Stakeholders Theory is that the change in the management model can occur from the business strategy (FREEMAN, 1984). A change leads to stakeholder integration in strategic planning and management (PLAZA-ÚBEDA, 2010). And the strategic vision provided to the organization of "who" is in fact the Stakeholder, defined by three aspects: (i) descriptive aspect: it is concerned with identifying the needs and interests depending on the business; (ii) instrumental aspect: it aims at evaluating the impact on the organization's performance for its continuous improvement (iii) normative aspect: it has the purpose of giving due recognition of its importance (FREEMAN, 1984; DONALDSON; PRESTON, 1995).

After the development of the Stakeholder Theory (80's), several studies have gained space with the purpose of conceptualizing and categorizing the typologies of Stakeholders (BRUGHA; VARVASOVSZKY, 2000). The studies are discussed (SOLEIMANI; SCHNEPER; NEWBURRY, 2014) and offer different views of the classifications of Stakeholders (CLARKSON, 1995; DONALDSON; PRESTON, 1995; MITCHELL; AGLE; WOOD, 1997). For this study, we adopted the classification of Stakeholders proposed by Clarkson (1995), highlighted below:

a) Primary Stakeholders: customers, suppliers, investors, employees, among others, committed to the survival of the company and have a relationship of interdependence between the stakeholders (CLARKSON, 1995).

b) Secondary Stakeholders: composed of "those who influence or affect, or are influenced or affected by, the company, but do not have direct contact with the transactions and are not essential for its survival" (CLARKSON, 1995), e.g., the media, government and local community (VASI; KING, 2012).

Another outstanding classification is by Mitchell, Agle and Wood (1997), who created the Stakeholder Salience Model with the objective of stating the importance of each Stakeholder before the perceptions of the managers. In the Stakeholder Salience model, stakeholders' capacity influences organizations in the face of attributes of power, legitimacy and urgency (TASHMAN; REALIN, 2013).

Mainardes, et al., (2011) Highlight that the two types of relevant stakeholders are latent - which have only one attribute and receive little attention from the company; and expectant - who have two attributes and have a more active posture. Given the definitions and classifications of Stakeholders presented, it is necessary for organizations to define who they are and what the needs and desires of the Stakeholders are in order to guide the strategies and obtain value creation in the business (AGLE; MITCHELL; SONNENFELD, 1999).

We can also observed that the definition of stakeholders is a condition for evaluating the performance of the business (FREEMAN, 1984; CLARKSON, 1995; DONALDSON; PRESTON, 1995). To emphasize this emphasis, the Performance Prism Model is proposed.

\subsection{Performance Prism}

Neely, Gregory and Platts (1995), Neely (1999), Neely, Adams and Crowe (2001), proposed the PP as a performance evaluation model (NEELY; KENNERLEY; ADAMS, 
2002) used in several areas (SMULOWITZ, 2015, NAJMI; ETEBARI; EMAMI, 2012; YOUNGBANTAO; ROMPHO, 2015).

Neely (2007) highlights the PP as a response to criticism from previous models such as the Balanced Scorecard (KAPLAN and NORTON, 1997), and built on four aspects (NEELY, ADAMS and CROWE, 2001).

Initially, for Neely (2007, p.141-142) "the PP unifies other measures (e.g. Stakeholders, employees, suppliers) and is built upon the strengths of individuals in the organization. "Second, the model incorporates budgetary measures (e.g. management cycles, front-line teams, forecasts) and the degree of adaptation of the company, aiming at raising performance (NEELY; ADAMS; CROWE, 2001). Third, the model enhances the subjectivity that exists in accounting practice, as it exists in the valuation of goodwill and in the application of depreciation (NEELY, 2007). For Neely, Adams and Kennerley (2002, p.142), this improvement occurs because "some accountants orientations assume that they reflect the truth". Fourth, the model advances the distinction between the value of a measure and the performance of a measure, generating points of reflection and dependence on the two elements (NEELY, 2007).

Figure 1 presents the PP. The first dimension is stakeholder satisfaction, which seeks to understand the key stakeholders and their needs, since these agents play a fundamental role in the organization's performance (NEELY, 2007).

The second dimension, strategy, weighs whether strategies are implemented, communicated within the organization, encouraged by employees and whether they are as planned (NEELY; ADAMS; CROWE, 2001). We highlight that the company should seek answers to the question: what strategies should be put into practice to meet the needs and desires of the organization's key stakeholders? (NEELY; ADAMS; KENNERLEY, 2002).

The processes correspond to the structure of the demand, the development of the product or service and the management of the organization (NEELY, 2007). For Neely, Adams and Crowe (2001), the processes dimension concerns what makes the organization work. From

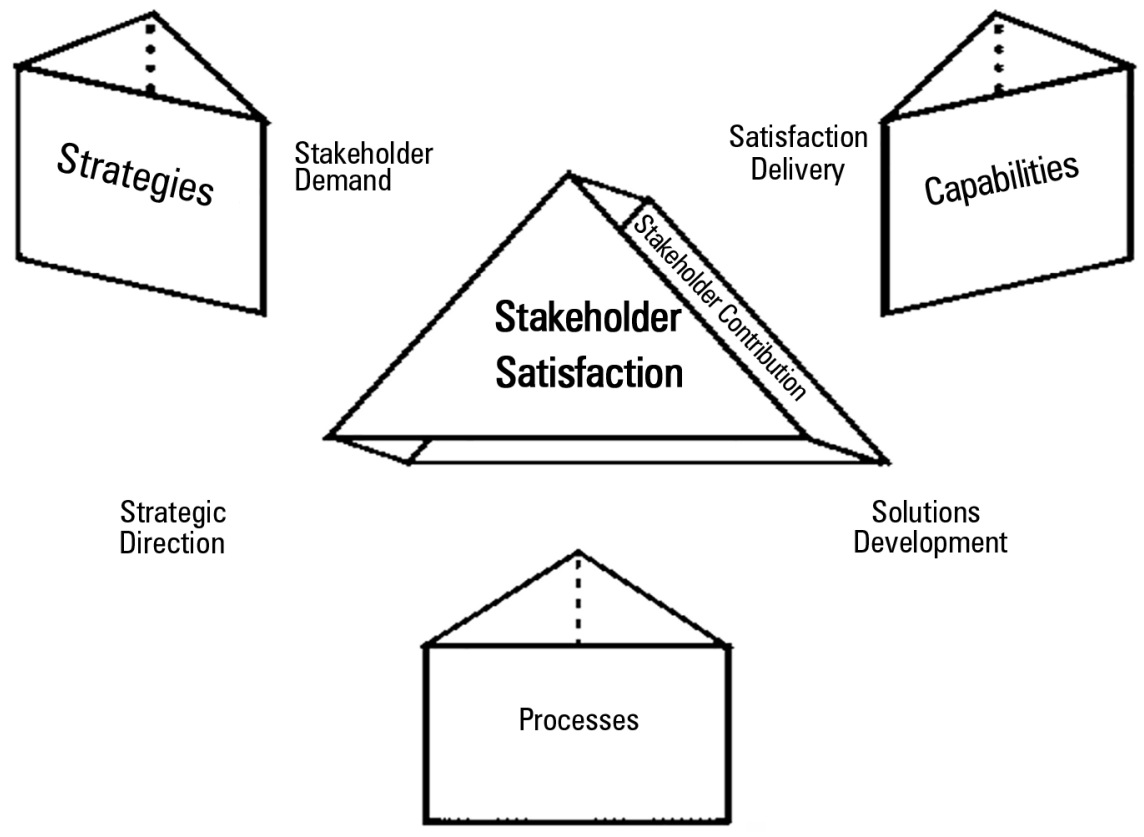

Source: Neely, Adams and Crowe (2001).

Figure 1. Performance Prism Model. 
BBR

15,2

124

the point of view of measurement, the critical aspects are: quality, quantity, time, ease of use and finances (NEELY, 2007). According to Neely and Adams (2001), the main question of this facet is: What are the critical processes we need to operate and grow these processes?

Capacities are the competencies and skills that the parties involved need to have for the operationalization of the short and long term processes, through a combination of people, practices, technology and infrastructure (NEELY; ADAMS; KENNERLEY, 2002). Sometimes organizations need to understand what their capabilities are in terms of production, distribution, credit management, consumer needs and market structure (NEELY, 2007).

Finally, the stakeholder contribution emphasizes that not only should the organization contribute to stakeholders, but stakeholders should also return the benefits to the organization (NEELY, 2007). For Neely, Adams and Crowe (2001), the stakeholder contribution is associated with consumer satisfaction, as it meets the needs of investors, consumers, distributors, employees, regulatory agencies, communities and suppliers. Based on what has been discussed, Figure 1 presents the Performance Prism.

\subsection{Stakeholder Theory and the Performance Prism Model}

When considering the interests of other Stakeholders, in addition to the owner, the Stakeholder Theory inserts the analysis of other elements in the performance evaluation (FREEMAN, 1984). These elements are part of a complete elaboration of the organizational strategy in order to meet the needs and wishes of the Stakeholders (HARRISON; FREEMAN, 1999; FROOMAN, 1999). From an economic and social perspective, the organization goes through the creation and distribution of increased wealth and value for all (CLARKSON, 1995). In this context, a point of relationship between the two elements can occur through the fact that the PP takes into account the perspective of the stakeholder for the formation of performance measurement metrics, generating social value to interest groups.

In Clarkson's (1995) perspective, an organization can move towards performance when there is clarity and recognition of needs, desires, responsibilities and obligations with all Stakeholders, being fundamental to observe the position of the stakeholders and to understand what is expected in terms of performance to satisfy the different stakeholders. In this connection, a second point of relationship between the two elements can occur through description of indicators of needs, desires, expectations and stakeholder satisfaction to measure as inputs in the formation of organizational strategies.

Based on the aforementioned, the PP complements Clarkson's (1995) point of view when analyzing $(i)$ who are the most relevant stakeholders for the organization's operation, (ii) what these agents expect and desire from the company and (iii) what the organization wants from these interest groups, through the perspectives of stakeholder satisfaction and contributions.

\section{METHOD}

The method we used is the case study, since it analyzes several companies as a phenomenon of study (THOMAS, 2015), grouping the findings around the key qualitative terms. In the study, we considered MSMEs, configuring a case study with multiple cases (HANCOCK; ALGOZZINE, 2015; SMITH, 2007). The organizations are located in the states of Mato Grosso do Sul, Rio Grande do Sul and Paraná.

Stake (1978) distinguishes three types of case studies from the purposes: intrinsic (understanding of a case), instrumental (the understanding of something wider) and 
collective (the author collectively studies some cases to investigate a given phenomenon). The type of case study we used in the research is the multiple case type (STAKE, 1978), as it deals with multiple MSMEs to understand stakeholder dynamics. Regarding the nature of the objective of this research, we adopted the interpretative case study type, which "seeks to describe in detail a phenomenon studied and to find patterns in evidence, developing conceptual categories that make it possible to illustrate, confirm or oppose theoretical assumptions" (DA-SILVA et al, 2010, p.124).

The search for several companies in a random way is indicated for qualitative research (SEAWRIGHT; GERRING, 2008). In total, seven MSME's were selected and the number of cases was defined by saturation, allowing the comparison and obtaining more robust evidence (DA-SILVA et al, 2010).

For the Selection of Cases we adopted the criterion of Several Cases, seeking to contrast different organizational dynamics and "cover a wide variation in order to reinforce the representativeness of the sample of cases chosen" (SEAWRIGHT; GERRING, 2008, p.301). The selection was made based on the criteria: (1) type of sales to the final consumer (clothes workshop) and to the corporate consumer (distribution network of beverages); (2) type of service companies (network of auto centers) and products (distributor of electrical materials); (3) billing volume; (4) gender of the manager (male gender of the manager (male vs. female); and (5) number of employees. The criterion of selection of the studies meets the requirements by Curtis et al (2000, p.1002), being "sequential by a rolling process".

In the Evidence Collection stage interviews were conducted via recorded messages (with the consent of the interviewees) and transcribed. The open semi-structured interview script follows the proposal by Neely, Adams and Crowe (2001) with two questions for each aspect of the PP analyzed: satisfaction and contribution of stakeholders. In order to understand and interpret managers' perceptions regarding the understanding of who are the most relevant stakeholders for their business and what are the satisfactions and contributions that their company needs to be aware of, we opted for this method of collecting because it "allows us to obtain a great deal of information, providing the researcher with the opportunity to clarify and segment questions and answers in a direct and flexible interaction" (DA-SILVA et al, 2010, p.306).

In methodological terms, caution should be exercised for Limiting the key Construct in the study for the purpose of theory development (PARKHE, 1993). In this regard, to increase the rigor of the research and define the element of theoretical discussion, we opted to study the two dimensions of the PP that deal with stakeholder: contribution and satisfaction. This delimitation of the construct and scope seeks to ensure greater reliability of the findings (EISENHARDT, 1991). Table 1 presents the research constructs, as well as their purposes, which are referenced in the studies by Neely, Adams and Crowe (2001).

In the Evidence Analysis we used the narrative analysis technique of the gnosis type. "succession of events is of less importance than the perception one has of them, the degree of knowledge one has or can acquire from them" (DA-SILVA et al, 2010, p.410).

The choice of the narrative analysis technique also allows the "absence of the receiver" at the moment of responses (DA-SILVA et al, 2010, p.406), since they were recorded and subsequently transcribed. We conducted the analysis of the narratives in five phases: (1) organization: ordering of the recordings, according to the semi-structured script for transcription; (2) transcription of interview recordings; (3) fluctuating reading: search for preliminary knowledge of narratives; (4) exploration of the material: moment of refining the narratives to generate comprehension of the text, in a more detailed way, guided by the defined methodology; and (5) treatment of evidence: inference and interpretation of narratives. 
Table 1. Constructs of the research

\begin{tabular}{|c|c|c|}
\hline Construct & Question & Objective \\
\hline \multirow{2}{*}{$\begin{array}{l}\text { Stakeholder satisfaction (NEELY; } \\
\text { ADAMS; CROWE, 2001) }\end{array}$} & $\begin{array}{l}\text { In your opinion, who are the most important } \\
\text { people or institutions to run your business? }\end{array}$ & $\begin{array}{l}\text { To comprehend the understanding of the } \\
\text { managers regarding the recognition of who are } \\
\text { the main stakeholders that generate value to } \\
\text { their business. }\end{array}$ \\
\hline & $\begin{array}{l}\text { What do you think each of these people or } \\
\text { institutions need from your company? }\end{array}$ & $\begin{array}{l}\text { To understand and interpret how managers } \\
\text { understand and perceive the needs and desires } \\
\text { of the stakeholders involved. }\end{array}$ \\
\hline \multirow{2}{*}{$\begin{array}{l}\text { Contribution of Stakeholders } \\
\text { (NEELY; ADAMS; CROWE, 2001) }\end{array}$} & $\begin{array}{l}\text { As a company manager, what do you want from } \\
\text { these people or institutions? }\end{array}$ & $\begin{array}{l}\text { To comprehend the understanding of the } \\
\text { managers on the clarity regarding the return } \\
\text { that one has or is expected from the main } \\
\text { Stakeholders involved. }\end{array}$ \\
\hline & $\begin{array}{l}\text { What do you actually receive as a result, when } \\
\text { the interests of the actors relevant to your } \\
\text { business are met? }\end{array}$ & $\begin{array}{l}\text { To understand and interpret whether there is a } \\
\text { perception by managers that key Stakeholders } \\
\text { help the company achieve its objectives. }\end{array}$ \\
\hline
\end{tabular}

Source: Adapted from Neely, Adams and Crowe (2001)

\section{RESULTS}

\subsection{Multiple Case Analysis}

Table 2 describes the main characteristics of the 7 MSMEs surveyed, related to the variables that highlight the number of employees, revenue, foundation, size, gender and location. We option that the companies remain anonymous, and show that on average the operating time is 17 years.

The selected cases are located in three states. The supermarket is set up as a small business and is situated in the fourth largest city of Paraná. The distributor of hydraulic materials and connections focuses on industrial sales to construction companies, being the largest distributor in the city. The clothing atelier makes women's clothing. The average value of each piece is 2,500.00 (BRL), ranging from 1 thousand to 50 thousand (BRL).

The engineering and asphalt paving company operates in several segments: highways, industrial infrastructure and asphalt production. The multi-store network (15) of Auto Centers focuses on the sale of tires, wheels and vehicle accessories, operating in the capital of RS. This company recently underwent through the implementation of the stakeholder concept.

In addition, a franchisee that is part of Brazil's largest residential and industrial security and monitoring network was part of the selection of cases. The manager of the local franchisee was interviewed and provided the basis for, limiting the interpretation to that unit. Finally, a network of beverage distribution of a multinational brand, which is present in more than 280 cities, was analyzed through the responses of the managers.

For the interviews analysis, we used the narrative analysis (DA-SILVA et al, 2010). The first dimension analyzed is the Stakeholder Satisfaction, addressed by the question: In your opinion, who are the most important people or institutions for your business to keep running? Bellow, we have the narratives of the respondents about the dimension of Stakeholder satisfaction:

In my opinion, the stakeholders are customers, employees, suppliers, managers, competitors and the state. For if one of these is missing, we lose the business cycle (...). [Acknowledgment of Stakeholders] (Supermarket).

[...]The most important people for our company are [sic] us, company directors [...].And, of course, Tigre, as a supplier, [...].And on the other hand constructing companies are our main focus as our clients. [...] Of course, the more the Caixa Econômica Federal (Bank) approves financing, [...].And if the government paid 
right, the constructors will be able to give us a good return. [...] [Acknowledgment of Stakeholders] (Distributor of Hydraulic Materials).

The basis of our company is our team, from embroiderers and seamstresses (outsourced) to saleswomen and stylists. [Acknowledgment of Stakeholders] (Atelier Company). We provide services to the population, all are important, [...] our job is to facilitate people's access and life, from the street where they live to the busiest highways [...] [Acknowledgment of Stakeholders] (Engineering company).

Our directors, who contribute their knowledge so that the projects can be carried out for the development and profitability of the company. Collaborators as a whole [...].Clients, as agents that keep our group strong and with the possibility of growth. Our suppliers, who make it possible to have competitive products with quality and differentiated prices. [Acknowledgment of Stakeholders] (Auto Centers Network).

I consider them as to be the suppliers, customers and employees of the company,.[ Acknowledgment of Stakeholders] (Franchisee monitoring company).

I consider them to be customers, suppliers and employees. [Acknowledgment of Stakeholders] (Beverage Distribution Network).

The analysis shows that the seven companies define Stakeholders to be: owners, customers, suppliers and employees. In this regard, we can observe that the Stakeholders of the organization are in agreement with that which is pointed out by Horneaux (2010) and Horneaux et al (2014). The PP suggests that stakeholder satisfaction shows how the organization views stakeholders in its business and acknowledges their wants and needs in order to seek solutions that serve those purposes (NEELY; ADAMS; CROWE, 2001).

We note that the company in the supermarket sector considers as relevant stakeholders to their business to be customers, employees, suppliers, managers, competitors and the government. An interesting point raised is that this company was the only one to include in the list competitors as stakeholders, corroborating with Freeman (1984) and Freeman, Wicks and Parmar (2004), who emphasize all these actors as important parts for the elaboration of business strategies and they understand that the competition motivates them for the continuous improvement of the company.

The distributor of hydraulic materials, complementarily, considers, in addition to all the actors mentioned above, the banks as significant for the operation of their enterprise. The bank was an element discussed by Neely (2007) as a financial actor relevant to the business in terms of economic and financial transactions. Finally, the company in the segment of Clothing Atelier pointed to the production and sales teams as the most important Stakeholders for the operation of its business. These teams may be internal or even external (outsourced apparel faction). Therefore, this latter organization seems to observe the employees or the teams as elements of union for the business.

Table 2. Cases analyzed in the multiple study

\begin{tabular}{lcccccc}
\hline Company & $\begin{array}{c}\text { No. of } \\
\text { Employees }\end{array}$ & $\begin{array}{c}\text { Entrepreneur's } \\
\text { Gender }\end{array}$ & $\begin{array}{c}\text { Time of } \\
\text { Existence }\end{array}$ & $\begin{array}{c}\text { Classification according } \\
\text { to the Revenue Service }\end{array}$ & State & Annual revenue \\
\hline Neighborhood Supermarket & 10 & Female & 29 (years) & Micro Enterprise & PR & 2.1 million (BRL) \\
Distributor of Hydraulic Materials & 15 & Female & 19 (years) & Small Enterprise & PR & 7 million (BRL) \\
Party Clothes Atelier & 4 & Male & 24 (years) & Micro Enterprise & PR & NA \\
Engineering & 987 & Male & 20 (years) & Large Enterprise & PR & R1.2 billion (BRL) \\
Auto Centers Network & 139 & Male & 20 (years) & Medium Enterprise & RS & 72 million (BRL) \\
Monitoring Franchise & 20 & Female & 7 (years) & Micro Enterprise & MS & 1 million (BRL) \\
Beverage Distribution Network & 130 & Male & 9 (years) & Medium Enterprise & RS & 50 million (BRL) \\
\hline
\end{tabular}


BBR

15,2

128

Another relevant point in the analysis that has been identified is the Stakeholder denominated local community or population, as reported by the engineering company. The engineering company builds roads (product) for the Government (primary stakeholder), who authorizes the population (secondary stakeholder) to use it. The local community is then the secondary actor of product use.

Clarkson (1995), when classifying the types of Stakeholders, makes mention to all those that are affected or influenced by the organization, but are not essential for their survival and have no direct relation to the transactions, which could be the media, the government and the local community. In this regard, the population is essential for the survival of the company, since it does not make direct payments of the use of the road, but it does indirectly. Therefore, the secondary and primary elements already discussed by Vasi and King (2012) appear to be coherent and existent within the studied phenomenon.

In addition, according to the theoretical classification by Clarkson (1995), The respondent from the engineering firm suggests the population as a primary Stakeholder, because they understand that the built highways are not for the governments use, but for those who actually pay for the final product.

The second question used to measure and analyze the satisfaction dimension of the PP of Stakeholders is: And what do you think each of these people or institutions need from your company? (NEELY; ADAMS; CROWE, 2001). The analysis highlights the main factors of meeting the desires of stakeholders in the direction of their expectations in the relationship with the organization interviewed. It is worth noting that this issue measures the owners' perception of the desires and needs of stakeholders, as portrayed by the respondents:

For me, the employee sales their labor force in exchange for a cash benefit. The supplier gives visibility to their product and earns income. The client, [...] the Competitor, avoids monopoly, free initiative and fair competition. The state: development of the economy, generating employment and income for the state (taxes and fees). [Acknowledgement of Stakeholders' desires and needs] (Supermarket).

First, we, as directors, expect from our company to be "our breadwinner" [...]. For Tigre (supplier), [...]regarding sales sees us as a sure sale every month. For the construction companies, I believe it is the fact that they know they will find what they are looking for and that they will have the amount they need, [...]. Caixa Economica, as a bank, I believe it is the turnover of money [...]. and for the Government, the payment of taxes for sure[...]. [Acknowledgement of Stakeholders' desires and needs] (Distributor of Hydraulic Materials).

The team needs something in addition money [...]I FEEL that they have a great need to feel as an important part of the growth [...]. [Acknowledgement of Stakeholders' desires and needs] (Atelier Company).

[...]We have usually seen the population's satisfaction when the work is completed [...]. [Acknowledgement of Stakeholders' desires and needs] (Engineering company). Both management and employees need guidance, training, valuation, career plan and autonomy to carry out their activities. Suppliers need the group to work ethically and transparently, [...].Customers need our group to meet their needs, offering quality products and services [...]. [Acknowledgement of Stakeholders' desires and needs] (Auto Centers Network).

I believe that they expect our company to comply with the agreement, each one in its sphere, the collaborators, who have good working conditions and who receive the combined deadlines. The suppliers: that the payment of the obligations is carried out according to previous negotiations, [...].Customer and employee satisfaction 
are often measured, each in a different way. [Acknowledgement of Stakeholders' desires and needs] (Franchisee monitoring company).

We believe that they (customers) expect a good service delivery, with respect, agility, creativity and credibility [...]. [Acknowledgement of Stakeholders] (Beverage Distribution Network).

The findings showed that employees are expected to receive a monetary wage, the feeling of being a part of the business, giving opinions, receiving training and qualification, feeling valued, having a system of career plans in Human Resources, having autonomy to perform the tasks and having good working conditions. These responses are congruent with the aspect of acknowledgement of Stakeholders proposed by Donaldson and Preston (1995).

The findings pointed out that suppliers are looking for an improvement in sales, good product exposure, guaranteed or exclusive sales (long-term relationship), ethics, transparency and up-to-date payment. These observations are consistent with Harrison and Freeman (1999).

From competitors it is expected that there will be no monopoly creation, no single competition or timely and unilateral market aspects. These information shows how respondents are concerned about a possible dependency on a single provider for economic transactions.

The results show that managers believe that customers expect the convenience, personalized service, a list of products and mix of solutions that require an attractive price, a quality and agility and a responsible interaction of the company with the environment. From management it is expected that there will be a satisfactory remuneration, with consistent values.

The Contribution of Stakeholders perspective presupposes a relationship of interdependence between the organization and the actors that relate to it (NEELY; ADAMS; KENNERLEY, 2002). The question of the interview reported on: As a company manager, what do you want from these people and institutions? (NEELY; ADAMS; CROWE, 2001). The main responses from managers are:

We expect vendor partnership, customer loyalty and ethics, employee commitment to the growth of all. [Dimension of the Prism/Contribution of Stakeholders] (Supermarket).

[...]From me, (director) I hope that I give more orders to my employees, make them obey me and enable them to sell all the items we own. From Tigre (supplier),I hope she continues being our partner, always being able to give us [sic]exclusive prices and special conditions [...] From the Government, we expect them to properly apply our taxes, [...].From Caixa (bank), I hope that our manager will continue to see the best package for our needs [...].From the constructors (clients), I hope they will undertake more and more building works, that they succeed, that they will build more and more with their commitments up to date [...]. [Dimension of the Prism/ Contribution of Stakeholders] (Distributor of Hydraulic Materials).

We look forward to the team's commitment and dedication. This pursuit of a dream together with the company, both from senior employees and the new ones. [Dimension of the Prism/Contribution of Stakeholders] (Atelier Company).

We expect acknowledgment [...] [Dimension of the Prism/Contribution of Stakeholders] (Engineering company).

From the managers, dedication, commitment, seriousness with the Corporate Policies of the Company. [...].Employees - working in this Company as if they were owners, really engaging, compromised with the results, being confident about the company 
BBR

15,2

and meeting the need of the client. Customers - always leaving satisfied and suggesting our company to family and friends. Suppliers - work ethically, always offering the best negotiation conditions with sustainable margin and quality products. [Dimension of the Prism/Contribution of Stakeholders] (Auto Centers Network).

From employees, who perform the contracted functions, with disposition, punctuality, and since we offer a 24 hour service that they do it with extra commitment. From clients, who make the fair payment for the service performed in the agreed schedule, and also suggest the service to potential clients. From the suppliers, that the delivery of the contracted merchandise/service to be on time, according to what was agreed, with quality, warranty in cases that are necessary, and long-term partnership. [Dimension of the Prism/Contribution of Stakeholders] (Monitoring Franchisee).

We want them to continue to believe in our company, strengthening the relationship we have, to grow together more and more. [Dimension of the Prism/Contribution of Stakeholders] (Beverage Distribution Network).

In the process of Contribution of Stakeholders in the business, the owner expects from the supplier loyalty, partnership, better conditions for negotiations and delivery of the products within the agreed time. The respondent managers have the following expectations from the client: commitment, continuity in the purchase of the products, fair payment for the service and satisfaction. The continuity of the relationship between client and company is highlighted in aspects of the present, past or future, conditions reinforced by Clarkson (1995).

In addition, managers expect employees' personal growth, empowerment (or even with a use of power "obedience") commitment to results, trust in the company and customer orientation. These findings are congruent with stakeholders for the survival of the company, understood as primary stakeholders according to Clarkson (1995).

A significant evidence is on aspects of social responsibility and governance, as managers are expected to be dedicated, committed, serious about the corporate policies of the company, concerned about the environment, concerned about the quality of life and interaction with society.

The respondent from a company stressed his desire for continuity and mutual cooperation in the business, saying they want "that they [the agents involved] continue to believe in our company [supermarket], strengthening the relationship we have, to grow together more and more".

Another element related to the Contribution of Stakeholders is the organization's expectation regarding the actors involved (NEELY; ADAMS; KENNERLEY, 2002). Therefore, in terms of application, it means understanding what is the contribution of the actors previously mentioned by the manager as relevant to their company. In order to meet this prerequisite, the question presented to the respondent is: What do you actually receive as a result, when the interests of the actors relevant to your business are met? (NEELY; ADAMS; CROWE, 2001), According to respondents:

As a result, we receive feedback from customers and employees working more spiritedly and more efficiently.[Dimension of the Prism processes/Contribution Received Effectively] (Supermarket).

We have received the dedication of the directors, suppliers' partners and loyal customers and banks that recommend us. [Dimension of the Prism processes/ Contribution Received Effectively] (Distributor Hydraulic Materials).

We have received from the oldest ... And we are trying to put the younger ones in the same mood. [Dimension of the Prism processes/Contribution Received Effectively] (Atelier Company). 
Recognition, respect and especially recommendation[...]. [Dimension of the Prism processes/Contribution Received Effectively] (Engineering company).

We are immensely satisfied whenever our Employee delivers Quality Services, bringing to the company the Profit as a form of sustainability for company maintenance and growth, providing new business, generating new jobs [...]. [Dimension of the Prism processes/Contribution Received Effectively] (Auto Centers Network).

Our company receives it in several ways, for example, if employees perform a quality service in the delivery to the customer, the customer will be satisfied and will recommend the services performed for other clients, and will make the payments on time, Which will enable a more effective partnership with suppliers obtained through the discharge of commitments as agreed. [Dimension of the Prism processes/ Contribution Received Effectively] (Monitoring Franchise).

Our main result for the work we carry out is our customers and partners who believe in our company and make it grow more and more. [Dimension of the Prism processes/ Contribution Received Effectively] (Beverage Distribution Network).

Evidence shows that companies receive the employee's determination in terms of motivation to stay in business, the respect of the municipal or state government in terms of the product it delivers, customer satisfaction in terms of purchase and commitment to continue and the belief and expectation of prosperity regarding the suppliers' businesses, so that all the agents involved win in the relationship.

The responses also highlighted expectations of continuity and partnership over time for business prosperity. In this regard, the element of expectations of continuity and partnership is proposed as a dimension to evaluate the stakeholder. This new perspective is not in the PP, but is discussed separately by Leach et al (2002). Therefore, there is theoretical and empirical support for the proposal of this dimension, which can be useful to redefine sustainable organizational development (BÄCKSTRAND, 2006).

\section{FINAL CONSIDERATIONS}

Based on the perspective of Stakeholders Theory and two dimensions of the PP model, we identify the perspectives of the Stakeholders present in the performance evaluation.

Stakeholders are understood as owners, customers, suppliers, employees, managers, competitors and government, banks and staff, these who are responsible for the union of the business. These definitions are aligned with Stakeholders Theory and arise in the responses of the companies surveyed, creating the need to build a broader view on who are the stakeholders that influence organizational performance.

The results showed that the owners expect from employees: motivation at work, efficiency and quality in the services provided; from suppliers: improvement of sales; from competitors: that there is no monopoly creation; from clients: a list of products and mix of solutions; from management: that there is a satisfactory remuneration, with coherent values and, finally, from the government: the payment of taxes and fees.

Results that allow us to understand how the organizational strategy will be shaped from the needs of the owners on the various agents that define, construct and represent the stakeholders. Also, they are possible indicators to define and achieve multiple organizational goals.

Although it is common for external influence to prevail on the organization, there is the perspective of the contribution of Stakeholders in the opposite direction. The owner expects to give a bigger return to the business with more action in the definition and direction of the company. In this context, respondents expect to increase the value of the business and stakeholders, as proposed by Neely, Adams and Crowe (2001). 
BBR

15,2

132

In the research, a new dimension is identified to evaluate the stakeholder, defined as Continuity and Partnership Expectations. It is a perspective of future thinking for the assessment of MSME's and the survival of all involved in the business, highlighted by Leach et. al (2002) and Bäckstrand (2006). We can observe that the relationship and loyalty of a customer's purchase will be continuous from the added value over time, resulting in profitability (REINARTZ; KUMAR, 2000).

Research is limited by cases and the random choice. It is a non-probabilistic type selection, determined by subjects that represent characteristics of different business models, size, among other variables. There is a risk to the analysis, since different points of view can be generated when interviewed by other managers. For a more robust contribution, a more homogeneous selection of cases is needed.

The research indicates the importance of knowing the needs and desires, as well as the retribution of the main stakeholders to reach the goals and targets, in relation to business practice. However, to consolidate the theoretical contribution, it is necessary to develop future research on this new perspective, in line with the PP model. Another proposal is to use the Stakeholder Salience Model with the objective of stating the importance of each Stakeholder in face of the perceptions of managers and to advance in the highlighted results, considered as critical to organizational performance (MITCHELL, AGLE and WOOD 1997).

\section{REFERENCES}

AGLE, B. R.; MITCHELL, R. K.; SONNENFELD, J.A. Who matters to Ceos? An investigation of stakeholder attributes and salience, corporate performance, and Ceo values. Academy of Management Journal, v. 42, n. 5, p. 507-525, 1999.

BÄCKSTRAND, K. Multi-stakeholder partnerships for sustainable development: rethinking legitimacy, accountability and effectiveness. European Environment, v. 16, n. 5, p. 290-306, 2006.

BRIDOUX, F.; STOELHORST, J. W. Microfoundations for stakeholder theory: Managing stakeholders with heterogeneous motives. Strategic Management Journal, v. 35, n. 1, p. 107-125, 2014.

BRUGHA, R.; VARVASOVSZKY, Z. Stakeholder analysis: a review.Health Policy and Planning, v. 15, n. 3, p. 239-246, 2000.

CARPINETTI, L. C. R.; GALDÁMEZ, E. V. C.; GEROLAMO, M. C.. A measurement system for managing performance of industrial clusters: a conceptual model and research cases. International Journal of Productivity and Performance Management, v. 57, n. 5, p. 405-419, 2008.

CHOONG, K. K. Understanding the features of performance measurement system: a literature review. Measuring Business Excellence, v. 17, n. 4, p. 102-121, 2013.

CLARKSON, M. E. A stakeholder framework for analyzing and evaluating corporate social performance. Academy of Management Review, v. 20, n. 1, p. 92-117, 1995.

CURTIS, S.; GESLER, W., SMITH, G., WASHBURN, S. APProaches to sampling and case selection in qualitative research: examples in the geography of health. Social Science \& Medicine, v. 50, n. 7, p. 1001$1014,2000$.

DA SILVA, A.B.; GODOI, C.K.; BANDEIRA-DE-MELlO, R. Pesquisa Qualitativa Em Estudos Organizacionais: Paradigmas, Estratégias E Métodos. Editora Saraiva, São Paulo: 2010.

DONALDSON, T.; PRESTON, L. E. The stakeholder theory of the corporation: Concepts, evidence, and implications. Academy of Management Review, v. 20, n. 1, p. 65-91, 1995.

EISENHARDT, K. M. Better stories and better constructs: The case for rigor and comparative logic. Academy of Management Review, v. 16, n. 3, p. 620-627, 1991.

FREEMAN, R. E. Strategic planning: A stakeholder aPProach. Pitman, Boston, 1984.

FREEMAN, R. E. The politics of stakeholder theory: Some future directions. Business Ethics Quarterly, v. 4, n. 04, p. 409-421, 1994.

FREEMAN, R. Edward; REED, David L. Stockholders and stakeholders: A new perspective on corporate governance. California management review, v. 25, n. 3, p. 88-106, 1983.

FREEMAN, R. E.; WICKS, A. C.; PARMAR, B. Stakeholder theory and "the corporate objective revisited". Organization Science, v. 15, n. 3, p. 364-369, 2004. 
FROOMAN, J. Stakeholder influence strategies. Academy of Management Review, v. 24, n. 2, p. 191-205, 1999.

GARENGO, P.; BIAZZO, S.; BITITCI, U. S. Performance measurement systems in SMEs: a review for a research agenda.International Journal of Management Reviews, v. 7, n. 1, p. 25-47, 2005.

HANCOCK, D. R.; ALGOZZINE, B. Doing case study research: A practical guide for beginning researchers. $2^{\text {nd }}$. Edition.Teachers College Press, New York, 2015.

HARRISON, J. S.; FREEMAN, R. Edward. Stakeholders, social responsibility, and performance: Empirical evidence and theoretical perspectives. Academy of Management Journal, v. 42, n. 5, p. 479-485, 1999.

HOURNEAUX, F. J. Relações entre as partes interessadas (stakeholders) e os sistemas de mensuração do desempenho organizacional. 2010. Tese de Doutorado. Universidade de São Paulo.

HOURNEAUX, F. J.; SIQUEIRA, J. P. L.; TELlES, R.; CORRÊA, H. L. Análise dos stakeholders das empresas industriais do estado de São Paulo. Revista de Administração, v. 49, n. 1, p. 158, 2014.

JAMIL, C. M.; MOHAMED, R. Performance measurement system (PMS) in small medium enterprises (SMES): A practical modified framework. World Journal of Social Sciences, v. 1, n. 3, p. 200-212, 2011.

KAPLAN, R. S.; NORTON, D. P. A estratégia em ação: balanced scorecard. $21^{\text {a }}$ reimpressão. Rio de Janeiro: Elsevier: 1997.

KENNERLEY, M.; NEELY, A.. Measuring performance in a changing business environment. International Journal of Operations \& Production Management, v. 23, n. 2, p. 213-229, 2003.

LEACH, W. D.; PELKEY, N. W.; SABATIER, P. A. Stakeholder partnerships as collaborative policymaking: Evaluation criteria aPPlied to watershed management in California and Washington. Journal of Policy Analysis and Management, v. 21, n. 4, p. 645-670, 2002.

MAINARDES, E. W.; ALVES, H.; RAPOSO, M.; DOMINGUES, M. J. C. S. Um novo modelo de classificação de stakeholders. Anais do Encontro de Estudos em Estratégia (3Es), Porto Alegre, RS, Brasil, v. 5, 2011.

MCKNIGHT, B.; LINNENLUECKE, M. K. How Firm Responses to Natural Disasters Strengthen Community Resilience A Stakeholder-Based Perspective. Organization \& Environment, p.1-18, 2016.

MITCHELL, R. K.; AGLE, B. R.; WOOD, D. J. Toward a theory of stakeholder identification and salience: Defining the principle of who and what really counts. Academy of Management Review, v. 22, n. 4, p. 853-886, 1997.

NAJMI, M., ETEBARI, M. EMAMI, M. A framework to review Performance Prism, International Journal of Operations \& Production Management, v. 32, n.10, p.1124-1146, 2012.

NEELY, A.Business Performance Measurement: unifying theory and integrating practice. Cambridge University Press, Cambridge, UK, 2007.

NEELY, A. The performance measurement revolution: why now and what next?. International Journal of Operations \& Production Management, v. 19, n. 2, p. 205-228, 1999.

NEELY, A.; ADAMS, C.; CROWE, P. The PP in practice. Measuring Business Excellence, v. 5, n. 2, p. 6-13, 2001.

NEELY, A.; ADAMS, C.; KENNERLEY, M. The performance prism: The scorecard for measuring and managing business success. London: Prentice Hall Financial Times, 2002.

NEELY, A.; GREGORY, M.; PLATTS, K. Performance measurement system design: a literature review and research agenda. International Journal of Operations \& Production Management, v. 15, n. 4, p. 80-116, 1995.

NOGNING, F. L.; GARDONI, M. Performance Double Prism: A performance measurement system for exploration and exploitation innovations in manufacturing SMEs. In: Industrial Engineering and Operations Management (IEOM), 2015 International Conference on. IEEE, 2015. p. 1-10.

PARKHE, A. "Messy" research, methodological predispositions, and theory development in international joint ventures. Academy of Management Review, v. 18, n. 2, p. 227-268, 1993.

PLAZA-ÚBEDA, J. A.; DE BURGOS-JIMÉNEZ, J.; CARMONA-MORENO, E. Measuring stakeholder integration: knowledge, interaction and adaptational behavior dimensions. Journal of Business Ethics, v. 93, n. 3, p. 419-442, 2010.

REINARTZ, W. J.; KUMAR, V. On the profitability of long-life customers in a noncontractual setting: An empirical investigation and implications for marketing. Journal of Marketing, v. 64, n. 4, p. 17-35, 2000.

REINARTZ, W. J.; KUMAR, V.The impact of customer relationship characteristics on profitable lifetime duration. Journal of Marketing, v. 67, n. 1, p. 77-99, 2003.

RODRIGUE, M.; MAGNAN, M.; BOULIANNE, E. Stakeholders' influence on environmental strategy and performance indicators: A managerial perspective. Management Accounting Research, v. 24, n. 4, p. 301$316,2013$. 
SEARCY, C. Corporate sustainability performance measurement systems: A review and research agenda. Journal of Business Ethics, v. 107, n. 3, p. 239-253, 2012.

SEAWRIGHT, J.; GERRING, J. Case selection techniques in case study research a menu of qualitative and quantitative options. Political Research Quarterly, v. 61, n. 2, p. 294-308, 2008.

SEIDMAN, I. Interviewing as qualitative research: A guide for researchers in education and the social sciences. Teachers college press, New York, 2013.

SMITH, J. A. (Ed.). Qualitative psychology: A practical guide to research methods. Sage, Thousand Oaks, 2007.

SMULOWITZ, S. Evidence for the PP in higher education, Measuring Business Excellence, v.19, n.1, 70-80, 2015.

SOLEIMANI, A.; SCHNEPER, W. D.; NEWBURRY, W. The impact of stakeholder power on corporate reputation: A cross-country corporate governance perspective. Organization Science, v. 25, n. 4, p. 9911008, 2014.

SOUSA, G. W. L. et al. Conceptual design of performance measurement and management systems using a structured engineering aPProach.International Journal of Productivity and Performance Management, v. 54, n. 5/6, p. 385-399, 2005.

SOUSA, S. D.; ASPINWALL, E. M.; RODRIGUES, A G. Performance measures in English small and medium enterprises: survey results. Benchmarking: An International Journal, v. 13, n. 1/2, p. 120-134, 2006.

STAKE, R. E. The case study method in social inquiry. Educational Researcher, v. 7, n. 2, p. 5-8, 1978.

STAKE, R. E. Multiple case study analysis. Guilford Press, New York, 2013.

STRITESKA, M.; SPICKOVA, M. Review and comparison of performance measurement systems. Journal of Organizational Management Studies, v. 2012, n. 1, p. 1-13, 2012.

TASHMAN, P.; RAELIN, J. Who and what really matters to the firm: Moving stakeholder salience beyond managerial perceptions. Business Ethics Quarterly, v. 23, n. 04, p. 591-616, 2013.

THOMAS, G. How to do your case study. Sage, Thousand Oaks, 2015.

VASI, I. B.; KING, B. G. Social movements, risk perceptions, and economic outcomes the effect of primary and secondary stakeholder activism on firms' perceived environmental risk and financial performance. American Sociological Review, v. 77, n. 4, p. 573-596, 2012.

WU, D. Measuring performance in small and medium enterprises in the information \& communication technology industries. 2009. Doctoral Dissertation. RMIT University, Melbourne, Australia.

YIN, Robert K. Estudo de Caso: Planejamento e Métodos. Bookman, Porto Alegre, 2001.

YOUNGBANTAO, U.; ROMPHO, N. The Uses of Measures in PP in Different Organizational Cultures. Journal of Accounting and Finance, v. 15, n. 6, p. 123, 2015. 